\title{
Effectiveness and safety of lixisenatide for treatment of diabetes in the real world: data from the Monitoring Registry in a Real-Life Cohort in the Czech and Slovalk Republic
}

\author{
Martin Haluzík', Alena Adamíková2, Milan Běhunčík ${ }^{3}$ Marek Macko ${ }^{4}$, Radka Štěpánová5 \\ 'Department of Diabetes, Institute for Clinical and Experimental Medicine (IKEM), Prague, Czech Republic \\ ²Department of Internal Medicine IPVZ, Tomáš Bata Regional Hospital a.S., Zlín, Czech Republic \\ ${ }^{3}$ Department of Internal Medicine, Railway Hospital Košice, s.r.o. \\ ${ }^{4}$ DIABETOL, s.r.o., Prešov, Slovak Republic \\ ${ }^{5}$ Aprova, s.r.o., Brno, Czech Republic
}

\begin{abstract}
Summary
Introduction: GLP1 receptor agonist lixisenatide has demonstrated its efficacy in numerous clinical trials, nevertheless its real-life effectiveness data is limited. Aim: To describe effectiveness and safety of lixisenatide in routine clinical practice in the Czech Republic and the Slovak Republic, as recorded by the Registry-Based Observational Study. Methods: Multinational, multicenter, observational, non-interventional, 6-month prospective product registry of patients with type 2 diabetes mellitus aged $>18$ years who were initiating therapy with lixisenatide. Patients were enrolled into this registry, provided written informed consent, between 1 May 2013 and 31 December 2015. Evaluations were performed at baseline and after 3 and 6 months of lixisenatide treatment. The primary objective of the study was the absolute change in glycated hemoglobin $\left(\mathrm{HbA}_{1 \mathrm{c}}\right)$ from baseline to month 6 after lixisenatide initiation. The study was approved by responsible ethics committees and performed in accordance with the Helsinki Declaration. Informed consent was obtained from all patients before enrolment in the study. Results: Overall 772 eligible patients ( $51.4 \%$ males), mean age 56.7 ( \pm 9.3 ) years, with mean diabetes duration 7.7 ( \pm 5.5$)$ years, mean duration of treatment with oral antidiabetic drugs $6.8( \pm 4.9)$ years, and body mass index $37.6( \pm 5.9) \mathrm{kg} / \mathrm{m}^{2} \mathrm{were} \mathrm{en-}$ rolled in the study. Overall, $93.6 \%$ were obese, $86.3 \%$ subject were treated for hypertension, and $76.0 \%$ for dyslipidemia. In total $96.1 \%$ of patients completed the 6 months' therapy. Lixisenatide significantly reduced $\mathrm{HbA}_{1 \mathrm{c}}$ (decrease by $9.7 \pm 14.4 \mathrm{mmol} / \mathrm{mol}[3.1 \pm 0.2 \% \mathrm{DCCT}]$ after 6 months in per protocol population), and body weight (decrease by $3.5 \pm 5.4 \mathrm{~kg}$ ). The best responders to the treatment were younger patients with higher BMI, who had a shorter duration of diabetes. Overall safety profile of lixisenatide was satisfactory in the study. The most frequent adverse events were functional disorders affecting the gastrointestinal system. There was no episode of severe hypoglycemia reported throughout the study. Conclusion: In a real-life practice cohort of patients with type 2 diabetes mellitus 6 months treatment with once-daily GLP1 receptor agonist lixisenatide significantly improved glucose control and decreased body weight without increasing the risk of symptomatic and/or severe hypoglycemia risk. Funding: Sanofi Czech Republic.
\end{abstract}

Key words: GLP1 receptor agonist - glycated hemoglobin - $\mathrm{HbA}_{1 c}$ - lixisenatide - oral antidiabetic drugs (OAD) observational study - hypoglycemia - type 2 diabetes mellitus

\section{Účinnost a bezpečnost lixisenatidu v léčbě diabetu v reálném světě: údaje $\mathbf{z}$ monitorovacího registru z reálné praxe v České a Slovenské republice}

\section{Souhrn}

Úvod: Agonista receptoru pro GLP1 lixisenatid prokázal svou účinnost v četných klinických studiích, avšak údaje o jeho účinnosti z reálného života jsou omezené. Cíl: Popis účinnosti a bezpečnosti lixisenatidu v běžné klinické praxi v České republice a Slovenské republice, jak jsou zaznamenány v Observační studii na podkladě údajů z registru. Metody: Mnohonárodní multicentrický, observační, neintervenční, 6měsíční prospektivní produktový registr 
pacientů s diabetem 2. typu nad 18 let, kteří začínali léčbu lixisenatidem. Na základě informovaného písemného souhlasu byli pacienti do tohoto registru zařazeni v období od 1. května 2013 do 31. prosince 2015. Hodnocení byla provedena na začátku studie a dále po 3 a 6 měsících léčby lixisenatidem. Primárním cílem studie bylo dosažení zásadní změny v hodnotě glykovaného hemoglobinu $\left(\mathrm{HbA}_{1 c}\right) v$ období od počátku léčby do 6 . měsíce po zavedení lixisenatidu. Studie byla schválena př́slušnými etickými komisemi a proběhla v souladu s Helsinskou deklarací. Informovaný souhlas byl získán od všech pacientů před jejich zařazením do studie. Výsledky: Do studie bylo zařazeno celkem 772 pacientů ( $z$ toho $51,4 \%$ mužů) v průměrném věku $56,7( \pm 9,3)$ let, s průměrnou dobou trvání diabetu 7,7 ( $\pm 5,5)$ let, s průměrnou dobou léčby perorálními antidiabetiky (PAD) 6,8 $( \pm 4,9)$ let a indexem tělesné hmotnosti (BMI) 37,6 ( $\pm 5,9) \mathrm{kg} / \mathrm{m}^{2}$. Celkem 93,6 \% účastníků studie bylo obézních, $86,3 \%$ se léčilo pro hypertenzi a u 76,0 \% účastníků probíhala léčba dyslipidemie. Celkem 96,1 \% pacientů dokončilo 6 měsíční terapii. Lixisenatid významně snížil hodnotu $\mathrm{HbA}_{1 c}$ (pokles o 9,7 $\pm 14,4 \mathrm{mmol} / \mathrm{mol}[3,1 \pm 0,2 \%$ DCCT] po 6 měsících $\checkmark$ populaci per protokol), a tělesnou hmotnost (pokles o 3,5 $\pm 5,4 \mathrm{~kg}$ ). Nejlépe reagovali na léčbu mladší pacienti s vyšším BMI a s kratší dobou trvání diabetu. Celkový bezpečnostní profil lixisenatidu byl v rámci studie uspokojivý. Nejčastější nežádoucí účinky gastrointestinální. V průběhu celé studie nebyla hlášena žádná epizoda těžké hypoglykemie. Závěr: U skupiny pacientů s diabetem 2. typu v podmínkách běžného života se po 6 měsíční terapii při užívání agonisty receptoru pro GLP1 lixisenatidu 1krát denně významně zlepšila kompenzace diabetu a snížila tělesná hmotnost, aniž by se zvýšilo riziko symptomatické a/nebo těžké hypoglykemie. Financování studie: Sanofi Česká republika

Klíčová slova: diabetes mellitus 2. typu - GLP1 RA - HbA 1 - hypoglykemie - lixisenatid -observační studie - perorální antidiabetika (PAD)

\section{Introduction}

The prevalence of type 2 diabetes mellitus (T2DM) is significantly rising across the world, largely fueled by the epidemic of obesity and aging of the population [1]. T2DM is a progressive disease characterized by insulin resistance and decline of B-cell function [2,3]. Tight glycemic control is one of the cornerstones of effective management of T2DM, as it significantly reduces the risk of microvascular complications and may reduce the impact of macrovascular problems, particularly when achieved early in the disease course [4-6].

A variety of therapeutic options are available for the treatment of hyperglycemia in patients with T2DM. It is generally accepted that the initial therapy should consist of lifestyle changes plus metformin. The most recent American Diabetes Association/European Association for the Study of Diabetes guidelines suggest that if the individualized $\mathrm{HbA}_{\mathrm{lc}}$ target is not achieved with lifestyle modifications and metformin, a combination of metformin with any of six options should be considered, including the choice of injectables - basal insulin or a glucagon-like peptide 1 receptor agonists (GLP1 RAs) [7,8].

GLP1 RAs are the top prioritized class after metformin for monotherapy, dual therapy, and triple therapy in the American Association of Clinical Endocrinologists (AACE) algorithm [9]. By acting through GLP1 receptor GLP1 RAs stimulate postprandial insulin secretion and suppress glucagon release in a glucose-dependent fashion, and short-acting agents of this calls such as lixisenatide (Lyxumia ${ }^{\circledR}$ ), have a pronounced effect on delaying gastric emptying, resulting in a robust lowering of postprandial plasma glucose (PPG) [10-12]. When appropriately utilized, GLP1 RAs may grant results at least in line with pivotal trials [13].
Lixisenatide is a prandial GLP1 RA, administered oncedaily for the treatment of adults with T2DM, in combination with OADs and/or basal insulin. Lixisenatide has a marked effect on PPG, resulting at least in part form a slowing effect on gastric emptying. Specifically, data on the blood glucose lowering activity of lixisenatide once-daily demonstrated that, following administration in the morning, there was a significant pharmacodynamic effect on blood glucose levels throughout the day, showing that lixisenatide treatment reduces PPG at all meals. The pronounced postprandial effect of lixisenatide has been shown after both solid and liquid meals, which is accounted for by a sustained slowing of gastric emptying [14-17]. The drug possesses of low risk of hypoglycemia, and is effective across a wide disease, spectrum effective across a wide disease spectrum; the overall magnitude of $\mathrm{HbA}_{1 c}$ reduction has been found to be relatively similar throughout treatment stages, when used in monotherapy, in combination with one or two oral antidiabetic drugs or with insulin.

While the drug has been extensively studied in multiple randomized clinical trials (RCTs), additional data from larger, non-selected patient populations in the real-world environment are valuable complements, which may be more applicable to daily management of T2DM. Although observational (i.e. epidemiological) data can only describe the relationship between risk factors such as $\mathrm{HbA}_{1 \mathrm{c}}$ levels and disease related variables and are unlikely to provide guidance regarding the effect of therapy, they expand knowledge about efficacy and safety of treatments in the real-world conditions and help improved management of T2DM.

In the present observational study, we describe the effectiveness, treatment persistence and tolerability of 
lixisenatide in the real-life cohort of patients with T2DM in the Czech and Slovak Republic over 6 months' treatment period.

\section{Methods \\ Study Design}

This registry (Registry number: LIXISL06943) was a prospective, multinational, multicenter, observational 6-month product registry that followed 826 patients T2DM who initiated therapy with lixisenatide (622 in the Czech Republic and 204 in the Slovak Republic) in 156 centers (121 in the Czech Republic and 35 in the Slovak Republic). Patients were enrolled, provided written informed consent, between May 2014 and December 2015.

The physicians proposed for participation in the Registry were randomly chosen from the diabetologists who were familiar with GLP1 RAs therapy. The participating diabetologists were instructed to enroll each consecutive patient who met the inclusion criteria as described below and did not meet any of the exclusion criteria to participate in the Registry (with a target of 4-5 patients per site and a maximum of 8 patients). This consecutive enrollment of patients was aimed to limit the selection bias.

\section{Study Population}

All adult patients with T2DM regularly visiting a study physician (independently of the study). All patients were treated with lixisenatide, which was administered subcutaneously. The patients were selected from those for whom the participating physician had decided to prescribe lixisenatide irrespective of the study participation and who were willing to sign the Informed consent. For this study, the drug was not provided.

Patients were eligible for inclusion in the study population if they fulfilled all of the following criteria:

i. a recorded diagnosis of T2DM at any time prior to inclusion to the study

ii. male or female $\geq 18$ years at index

iii. GLP1 RA naive patients, not adequately controlled $\left(\mathrm{HbA}_{\mathrm{c}}>53 \mathrm{mmol} / \mathrm{mol}[>7 \% \mathrm{DCCT}]\right)$, for whom the participating diabetologists decided to initiate lixisenatide treatment within the 4 weeks before the inclusion, and

iv. written informed consent signed

Exclusion criteria were (i) diagnosis of type 1 diabetes mellitus at any time, (ii) pregnancy and lactation, (iii) actual participation in another clinical trial, (iv) patients not able to attend follow-up visits.

\section{Assessments and Data Collection}

Patients were followed from Inclusion visit (Visit 1) that was scheduled within 4 weeks after lixisenatide first prescription date. The data were recorded prospectively during evaluations at Inclusion visit and two follow-up visits within 6 months after treatment start. Available data obtained as close as possible to visits scheduled in month 3 and 6 were recorded. Baseline values of $\mathrm{HbA}_{1 \mathrm{c}}$ ( $\mathrm{mmol} / \mathrm{mol}$ or \% DCCT, depending on the country) and fasting plasma glucose (FPG; $\mathrm{mmol} / \mathrm{l}$ ) represented the most recent value recorded within 1 month prior to lixisenatide first prescription date (collected at Initiation visit). No additional test was required by the protocol in this observational study.

Data extracted during Inclusion visit, apart from inclusion and exclusion criteria, included demographic data, physical measurements and vital signs, medical history including records of diabetes and its complications, previous and current therapy with OADs and insulin, concomitant therapy for diabetes, records of lixisenatide therapy and baseline values of $\mathrm{HbA}_{1 \mathrm{c}}$ and FPG.

A patient reported outcome in a form of the Treatment Related Impact Measures-Diabetes (TRIM-D) questionnaire was used to investigate the subjects' satisfaction with anti-diabetic treatment and, also to assess satisfaction in relation to the change in therapeutic strategy. The questionnaire was handed out at Initiation visit and Visit 3.

Data extracted during Visit 2 and Visit 3 included actual values of $\mathrm{HbA}_{1 c}$ and $\mathrm{FPG}$, physical measurements and vital signs, daily glycemic profile (including twohour postprandial glycemia), change in therapy with insulin/OADs since previous visit, change in concomitant therapy for diabetes, occurrence of adverse events, occurrence of hypoglycemia. Micro- and macro-vascular complications data were those declared by the investigators. Hypoglycemia was classified as follows: in case of severe hypoglycemia patients were seeking medical attention or were admitted to hospital because of hypoglycemia; in case of symptomatic hypoglycemia all events with plasma glucose level $\leq 3.9 \mathrm{mmol} / \mathrm{l}$.

A simple questionnaire (5 points scale from "Very Good" to "Very Poor") collecting information on satisfaction with treatment was completed by a treating physician at Visit 3.

All adverse events (AEs) and serious adverse events (SAEs) together with their severity and relationship to the study treatment, were followed throughout the project. i.e. from signing of informed consent until the last visit and were documented at each visit and analyzed in the whole population recruited in the study. AEs were recorded in Adverse Event Form, SAEs were recorded both in Adverse Event Form and Safety Complementary Form by completion of relevant parts of eCRF.

Data were anonymously documented on electronic CRFs. Data from the patient questionnaire (paper version) which was asked to be completed by the patient during the visit were transferred to Aprova CRO for digitalization. If inspection of the data revealed potential inconsistencies, additional queries were sent to the investigator who was asked to respond by confirming or modifying the data questioned. Data quality control was performed in each participating country by qualified, designated personnel in at least $5 \%$ 
of active centers chosen at random, with at least one patient included. If specific issues were identified, the percentage of quality control in the concerned site/ country was appropriately increased and corrective actions implemented. The database was locked on February 26, 2016.

\section{Statistical Methods}

The primary endpoint of the study was change in glycemic control $\left(\mathrm{HbA}_{\mathrm{c}}\right)$ after 6 months of treatment with lixisenatide in the overall population (change in mean $\mathrm{HbA}_{1 \mathrm{c}}$ from most recent value obtained at Inclusion visit to the end of the study). The secondary endpoints were (i) percentage of patients with $\mathrm{HbA}_{1 \mathrm{c}}<53 \mathrm{mmol} / \mathrm{mol}[<7 \%$ DCCT] after 6 months, (ii) percentage of patients with decrease in $\mathrm{HbA}_{1 c}$ by at least $0.4 \%$, (iii) mean change in FPG, (iv) mean change in body weight, (v) incidence of adverse events, (vi) rates of symptomatic (plasma glucose level $\leq 3,9 \mathrm{mmol} / \mathrm{l}$ ), and severe (requires active help of another person) hypoglycemia occurrences, (vii) change in patients' satisfaction with the treatment (as reported by TRIM-D questionnaire) from baseline to end of the study, (viii) physicians' assessment of treatment at the end of the study.

All collected assessments were presented by means of descriptive analysis and calculation of confidence intervals. Descriptive analysis was carried out respecting the type of variable (i) continuous variables (e.g. age, $\mathrm{HbA}_{1 \mathrm{c}}$ ): number of available data $(\mathrm{N})$, arithmetic mean, standard deviation (SD), median, minimum (Min), maximum (Max), lower quartile, upper quartile, and 95\% confidence interval (if appropriate), (ii) categorical or discrete variables (e.g. number of AEs or hypoglycemia occurrences): absolute and relative frequencies, (iii) binary variables (e.g. sex): absolute and relative frequencies.

It was planned to include a total of 828 patients. The sample size was estimated to achieve a width of $95 \%$ confidence interval for a mean change in $\mathrm{HbA}_{1 \mathrm{c}}$ of at least $0.25 \%$ which is half of the clinically relevant change.

Two analysis populations were defined (i) eligible population, that covered the patients who have fulfilled inclusion criteria and who have received at least



one dose of lixisenatide and completed at least one follow-up visit, and who were not excluded according to the decisions taken during the data review, (ii) per protocol population (PP-population) that was defined as eligible patients who possessed available values for primary analysis (values of $\mathrm{HbA}_{1 \mathrm{c}}$ at baseline and after 6 months). PP-population was used for sensitivity anal-

\begin{tabular}{|c|c|c|}
\hline $\begin{array}{l}\text { baseline characteristics of } \\
\text { patients }\end{array}$ & $\mathrm{N}$ & values \\
\hline age (years) & 772 & $56.7( \pm 9.3)$ \\
\hline males $\mathrm{n}(\%)$ & 772 & $397(51.4 \%)$ \\
\hline duration of diabetes (years) & 772 & $7.7( \pm 5.5)$ \\
\hline previous treatment $\mathrm{n}(\%)$ & & 772 (100\%) \\
\hline $\begin{array}{l}\text { number of patients with } \\
\text { previous antidiabetic } \\
\text { medications }\end{array}$ & 772 & \\
\hline $\begin{array}{l}\text { number of patients with } \\
\text { previous OAD treatment }\end{array}$ & 772 & \\
\hline metformin n (\%) & & 738 (95.6 \%) \\
\hline sulfonylurea $\mathrm{n}(\%)$ & & $407(52.7 \%)$ \\
\hline DPP4 inhibitors n (\%) & & $249(32.3 \%)$ \\
\hline glitazon n (\%) & & $42(5.4 \%)$ \\
\hline glinid n (\%) & & $17(2.2 \%)$ \\
\hline SGLT2 inhibitors n (\%) & & $9(1.2 \%)$ \\
\hline $\begin{array}{l}\text { inhibitors of alpha-glucosi- } \\
\text { dase } n(\%)\end{array}$ & & $4(0.5 \%)$ \\
\hline $\begin{array}{l}\text { duration of OAD treatment } \\
\text { (years) }\end{array}$ & 659 & $6.8( \pm 4.9)$ \\
\hline $\begin{array}{l}\text { number of patients with } \\
\text { insulin treatment }\end{array}$ & 162 & \\
\hline $\begin{array}{l}\text { human insulin type NPH } \\
\mathrm{n}(\%)\end{array}$ & & $23(14.2 \%)$ \\
\hline insulin detemir n (\%) & & $39(24.1 \%)$ \\
\hline insulin glargine $n(\%)$ & & $100(61.7 \%)$ \\
\hline $\begin{array}{l}\text { baseline } \mathrm{HbA}_{1 \mathrm{c}}(\mathrm{mmol} / \mathrm{mol}) \\
{[\% \mathrm{DCCT}]}\end{array}$ & 772 & $74.09( \pm 13.0)[8.9 \pm 3.4]]$ \\
\hline FPG $[\mathrm{mmol} / \mathrm{l}]$ & 771 & $10.13( \pm 2.6)$ \\
\hline baseline weight (kg) & 772 & $110.0( \pm 19.1)$ \\
\hline $\operatorname{BMI}\left(\mathrm{kg} / \mathrm{m}^{2}\right)$ & 772 & $37.6( \pm 5.9)$ \\
\hline systolic BP $(\mathrm{mm} \mathrm{Hg})$ & 772 & $138.7( \pm 13.2)$ \\
\hline diastolic BP (mm Hg) & 772 & $82.2( \pm 8.9)$ \\
\hline
\end{tabular}

BMI - body mass index BP - blood pressure DPP4 - dipeptidyl peptidase-4 FPG - fasting plasma glucose, - high-density lipoprotein LDL low-density lipoprotein NPH - intermediate-acting insulin, OAD - oral antidiabetic drugs SGLT2 - sodium/glucose cotransporter 2 
ysis of primary endpoint. The PP-population was defined by eligible patients who have available values for primary analysis (values of $\mathrm{HbA}_{\mathrm{lc}}$ at baseline and after 6 months) and was employed for sensitivity analysis of primary endpoint. In case of missing $\mathrm{HbA}_{1 \mathrm{c}}$ value after 6 months of therapy with lixisenatide the Last Observation Carried Forward (LOCF) method was applied (a value of $\mathrm{HbA}_{1 \mathrm{c}}$ after 3 months of therapy with lixisenatide was used for analysis of primary endpoint).

\section{Compliance with Ethics}

Study was conducted in accordance with Good Epidemiology Practice (GEP), and applicable regulatory requirements. Conduct of this registry was approved by liable Ethics committees. Patients being enrolled into this registry provided written informed consent.

\section{Results \\ Patient's Flow Chart}

A total of 156 physicians, who were randomly selected from diabetologists with experience of GLP1 RA therapy, and who agreed to participate in the project, enrolled 826 patients into the study in the Czech Republic and Slovak Republic. Out of them, 54 patients were excluded, constituting an eligible population of 772 patients. Out of the excluded patients, 38 patients were excluded due to missing $\mathrm{HbA}$, values at both follow-up visits, 12 patients were excluded due to missing baseline $\mathrm{HbA}_{1 \mathrm{c}}$ values, and 4 patients were excluded for not fulfilling the inclusion criteria. From the eligible population, 35 patients were excluded due to missing $\mathrm{HbA}_{\mathrm{cc}}$ data for the primary analysis, resulting to PP-population of 737 patients (Figure 1).

The proportion of patients treated with lixisenatide remained quite stable over the course of the study with $96.1 \%$ of eligible patients still being treated after 6 months. In total 30 patients prematurely discontinued the study. The most common reasons for premature discontinuation over time were physician' decision listed in 9 patients (30.0\% of the reasons) and withdrawal by patient confirmed in 8 patients $(26.7 \%$ of the reasons). Overall, proportion of patients at Visit 1 was 772 , at Visit 2 (99.6 \%) and at Visit 3 (96.1\%).

\section{Demographics and baseline characteristics}

Patients' demographic characteristics together with details of their diabetes are presented in Table 1. Overall, the mean $( \pm S D$ ) age of the study population was 56.7 ( \pm 9.3) years. The age of the participants ranged between 22 and 77 years, with no difference in gender distribution: males (51.4\%) and females (48.6\%). Mean weight was $110.0( \pm 19.1) \mathrm{kg}$, mean BMI was $37.6( \pm 5.9) \mathrm{kg} / \mathrm{m}^{2}$ and $715(92.6 \%)$ of patients were obese. (The patients were classified as obese according to WHO classification obesity is a BMI greater than or equal to 30). Mean duration of disease was $7.7( \pm 5.5)$ years, mean $\mathrm{HbA}_{1 \mathrm{c}}$ value of eligible population was $74.1 \pm 13.0 \mathrm{mmol} / \mathrm{mol}[8.9 \pm$ $3.4 \%$ DCCT] and $74.1 \pm 13.1 \mathrm{mmol} / \mathrm{mol}[8.9 \pm 3.4 \%$ DCCT] PP-population, respectively.

At least one microvascular complication was reported in $213(27.6 \%)$ patients of the eligible population, mainly diabetic neuropathy in 130 (16.8\%) patients, diabetic nephropathy in $93(12.0 \%)$ patients, and diabetic retinopathy in $62(8.0 \%)$ patients. A macrovascular complication was reported in $85(11 \%)$ of patients with coronary artery disease being the most prevalent one. Overall, 506 (65.5\%) patients from eligible population were without diabetic complications at the time of initiation of treatment with lixisenatide.

Previous antidiabetic treatments were mostly oral antidiabetic drugs (OAD) with $610(79 \%)$ patients treated with at least one OAD, and 162 patients with combination of OAD and insulin. Treatment with insulin only was not recorded in any patient. In cases when therapy only with OADs was given, monotherapy was recorded 187 (24.2\%) of the cases, dual therapy in 269 (34.8\%), triple therapy in $148(19.2 \%)$, and quadruple therapy in $6(0.8 \%)$ cases. In patients taking OADs with insulin, it was most frequently recorded 1 OAD and 1 insulin $(n=$ $77 ; 10.0 \%$ ), followed by patients taking 2 OADs and 1 insulin $(n=61 ; 7.9 \%)$. Mean duration of OAD treatment was $6.8( \pm 4.85)$ years, and the duration of insulin treatment was 3.4 ( \pm 3.72 ) years.

The most frequent concomitant diseases were arterial hypertension in 666 patients (86.3\%), and dyslipidemia in 587 patients (76.0\%), patients were concomitantly treated predominantly with RAS blockers (68.8\%), statins (54.5\%), and betablockers (43.9\%).

\section{Outcomes}

Primary efficacy analysis was performed on eligible population (with LOCF method applied for missing $\mathrm{HbA}_{1 \mathrm{c}}$ values) and on PP-population as well. The primary outcome of this study was the change in $\mathrm{HbA}_{1 c}$ between the baseline, when the patient was started on lixisenatide treatment and the last follow-up visit

\begin{tabular}{|c|c|c|c|c|c|}
\hline & $\mathrm{N}$ & baseline & after 6 months & difference & $p$ value \\
\hline $\mathrm{HbA}_{1 \mathrm{c}}(\mathrm{mmol} / \mathrm{mol})$ eligible pts & 772 & $72.0( \pm 14)$ & $64.8( \pm 14.9)$ & $-9.3( \pm 14.5)$ & $\mathrm{p}<0.001$ \\
\hline $\mathrm{HbA}_{1 \mathrm{c}}(\mathrm{mmol} / \mathrm{mol})$ PP-population & 737 & $74.1( \pm 13.1)$ & $64.4( \pm 14.8)$ & $-9.7( \pm 14.4)$ & $\mathrm{p}<0.001$ \\
\hline
\end{tabular}

$\mathrm{HbA}_{1 \mathrm{c}}$ - glycated hemoglobin 
(6 months). In the eligible population, the mean \pm SD change was $-9.3 \pm 14.5 \mathrm{mmol} / \mathrm{mol}(-0.9 \pm 1.3 \%$ DCCT $)$, and in the PP-population the mean \pm SD change was $-9.7 \pm 14.4 \mathrm{mmol} / \mathrm{mol}(-0.9 \pm 1.3 \%$ DCCT $)$. All the changes from the baseline were statistically significant ( $\mathrm{p}<0.001)$, Table 2.

A higher decrease from the baseline in the values of $\mathrm{HbA}_{1 \mathrm{c}}$ was observed in the group which achieved a target $\mathrm{HbA}_{1 \mathrm{c}}$ levels $<53 \mathrm{mmol} / \mathrm{mol}[<7 \%$ DCCT] by visit 3 (Figure 2). It was also observed that the patients who didn't achieve a decrease in the levels of $\mathrm{HbA}_{1 c}$ by at least $0.4 \%$ by visit 3 , experienced an increase in the levels of $\mathrm{HbA}_{1 \mathrm{c}}$ (Figure 3).

Based on the subgroup analysis, it was observed that patients who were younger - mean $54,6( \pm 10,5)$ years with higher BMI - mean 38,6 $( \pm 6,4) \mathrm{kg} / \mathrm{m}^{2}$, and who had a shorter duration of diabetes - mean $6,1( \pm 4,8)$ years were more likely to achieve a target $\mathrm{HbA}_{1<}<53 \mathrm{mmol} / \mathrm{mol}[<7 \%$ DCCT] at the end of the study. Furthermore, the patients who achieved the target $\mathrm{HbA}_{\mathrm{lc}}<53 \mathrm{mmol} / \mathrm{mol}[<7 \%$
DCCT] were also less likely to have microvascular diabetic complications, specifically nephropathy, retinopathy and neuropathy, and suffered from less concomitant diseases. Moreover, these patients were less likely to need a change in insulin therapy and OAD treatment (Table 3).

The mean prescribed dose of lixisenatide was 10.1 $( \pm 0.80) \mu \mathrm{g}$ daily at the initiation of the treatment with a further increase to an average dose of $19.5( \pm 2.23) \mu \mathrm{g}$ daily at Visit 2, and 19.7 ( \pm 1.68) $\mu$ g daily at Visit 3.

Assessment of secondary objectives revealed that 137 patients (18.6\%) achieved $\mathrm{HbA}_{1 c}<53 \mathrm{mmol} / \mathrm{mol}[<7 \%$ DCCT]) after 6 months of therapy with lixisenatide in the PP-population. Overall 564 patients (76.5\%) achieved a decrease in $\mathrm{HbA}_{1 \mathrm{c}}$ by at least $0.4 \%$ from the baseline after 6 months of therapy with lixisenatide, in the PP-Population The mean change in FPG at the last follow-up visit was $-1.76( \pm 2.8) \mathrm{mmol} / \mathrm{l}$ in and this decrease was statistically significant $(p<0.001)$. A significant reduction in the mean body weight was observed over the study period. At last follow-up visit, the mean

\section{Figure 2. HbA $\mathrm{Ac}_{\mathrm{c}}$ values [mmol/mol] during lixisenatide therapy (subgroups by achievement target value of HbA} at Visit 3)

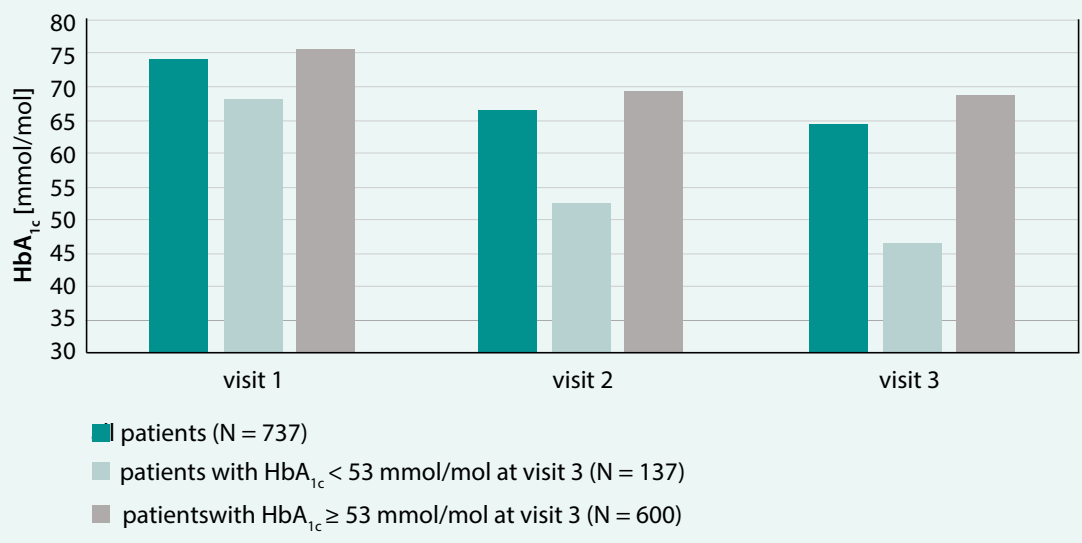

Figure 3. Change of $\mathrm{HbA}_{1 \mathrm{c}}$ values [mmol/mol] from baseline to the last follow-up visit (subgroups by decrease in $\mathrm{HbA}$ by at least $0.4 \%$ at Visit 3 )

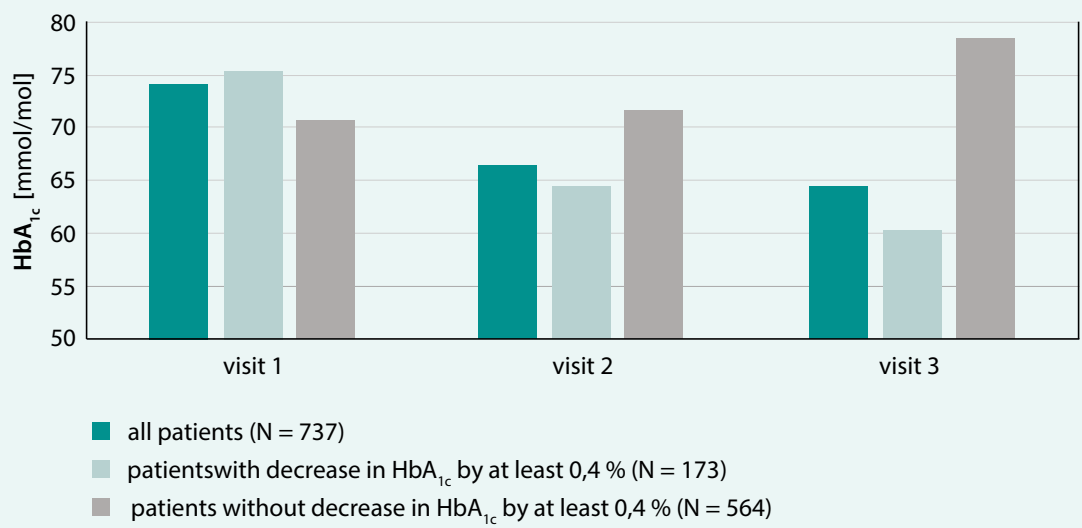


was $-3.5 \pm 5.4 \mathrm{~kg}$ and this decrease was statistically significant $(p<0.001)$ (Table 4).

Assessed by using Wilcoxon signed rank test or Student's t-test according to data normality

\section{Hypoglycemia}

Overall 14 patients experienced at least one episode of symptomatic hypoglycemia as confirmed by plasma glucose levels (PG) of $\leq 70 \mathrm{mg} / \mathrm{dl}(3.9 \mathrm{mmol} / \mathrm{l})$ during this study. No episode of serious, clinically significant hypoglycemia [PG $<54 \mathrm{mg} / \mathrm{dl}(<3.0 \mathrm{mmol} / \mathrm{l})]$ was documented throughout the study. The incidence of symptomatic hypoglycemia occurrences was more frequent between visit 1 and visit 2 (1.3\%) compared to the interval between visit 2 and visit $3(0.7 \%)$.
Overall Safety

Safety data were collected and recorded in all the $772 \mathrm{el}-$ igible patients throughout the study. Table 5 summarizes the frequency of all AEs, SAEs. A total of 25 adverse events (AEs) were reported in 23 patients (3.0\%) and 3 serious adverse events (SAEs) were reported in 3 patients $(0.4 \%)$ respectively, during the study. 13 AEs were related to study treatment and no SAEs was related to the study drug. The intensity of the adverse events was most frequently moderate (15 patients). These adverse events led to the discontinuation of the study treatment in 7 patients.

The most frequent events were functional disorders affecting the gastrointestinal system (14 patients), followed by infections in 3 patients. The gastrointestinal disorders included: nausea, vomiting, digestive diffi-

Tab. 3. Summary of changes in insulin and OADs therapy 6 months after starting lixisenatide treatment compared to baseline (as stratified by achievement of a composite target value of $\mathrm{HbA}_{\mathrm{ic}}$ at Visit 3 )

\begin{tabular}{|c|c|c|c|c|c|c|c|c|}
\hline insulin & \multicolumn{4}{|c|}{$\mathrm{HbA}_{1 \mathrm{c}}<53 \mathrm{mmol} / \mathrm{mol}$ at Visit 3} & \multicolumn{4}{|c|}{$\mathrm{HbA}_{1 \mathrm{c}} \geq 53 \mathrm{mmol} / \mathrm{mol}$ at Visit 3} \\
\hline patients & $\begin{array}{c}\text { at visit } 1^{1} \\
\mathrm{n}(\%)\end{array}$ & $\begin{array}{l}\text { between } \\
\text { visit } 1 \\
\text { and visit } 2 \\
\text { n (\%) }\end{array}$ & $\begin{array}{l}\text { between } \\
\text { visit } 2 \\
\text { and visit } 3 \\
\text { n (\%) }\end{array}$ & $\begin{array}{l}\text { during the } \\
\text { study }^{2} \\
\text { n (\%) }\end{array}$ & $\begin{array}{l}\text { at visit } 1^{1} \\
\text { n (\%) }\end{array}$ & $\begin{array}{c}\text { between } \\
\text { visit } 1 \\
\text { and visit } 2 \\
\text { n (\%) }\end{array}$ & $\begin{array}{l}\text { between } \\
\text { visit } 2 \\
\text { and visit } 3 \\
\text { n (\%) }\end{array}$ & $\begin{array}{l}\text { during the } \\
\text { study }{ }^{2} \\
\text { n (\%) }\end{array}$ \\
\hline $\mathrm{N}$ & $N=137$ & $N=136$ & $N=137$ & $N=137$ & $N=600$ & $N=598$ & $N=600$ & $N=600$ \\
\hline any change & $7(5.1 \%)$ & $5(3.7 \%)$ & $3(2.2 \%)$ & $13(9.5 \%)$ & $39(6.5 \%)$ & $50(8.4 \%)$ & $62(10.3 \%)$ & $112(18.7 \%)$ \\
\hline no change & 130 (94.9\%) & 131 (96.3 \%) & 134 (97.8 \%) & 124 (90.5 \%) & 561 (93.5 \%) & 548 (91.6 \%) & 538 (89.7 \%) & $488(81.3 \%)$ \\
\hline OADs & \multicolumn{4}{|c|}{$\mathrm{HbA}_{1 \mathrm{c}}<53 \mathrm{mmol} / \mathrm{mol}$ at Visit 3} & \multicolumn{4}{|c|}{$\mathrm{HbA}_{1 \mathrm{c}} \geq 53 \mathrm{mmol} / \mathrm{mol}$ at Visit 3} \\
\hline patients & $\begin{array}{l}\text { at visit } 1^{3} \\
\text { n (\%) }\end{array}$ & $\begin{array}{l}\text { between } \\
\text { visit } 1 \\
\text { and visit } 2 \\
\text { n (\%) }\end{array}$ & $\begin{array}{l}\text { between } \\
\text { visit } 2 \\
\text { and visit } 3 \\
\text { n (\%) }\end{array}$ & $\begin{array}{l}\text { during the } \\
\text { study }{ }^{4} \\
n(\%)\end{array}$ & $\begin{array}{l}\text { at visit } 1^{3} \\
\text { n (\%) }\end{array}$ & $\begin{array}{c}\text { between } \\
\text { visit } 1 \\
\text { and visit } 2 \\
\text { n (\%) }\end{array}$ & $\begin{array}{l}\text { between } \\
\text { visit } 2 \\
\text { and visit } 3 \\
\text { n (\%) }\end{array}$ & $\begin{array}{l}\text { during the } \\
\text { study }{ }^{4} \\
\text { n (\%) }\end{array}$ \\
\hline $\mathrm{N}$ & $N=137$ & $N=136$ & $N=137$ & $N=137$ & $N=600$ & $N=598$ & $N=600$ & $N=600$ \\
\hline any change & $38(27.7 \%)$ & $18(13.2 \%)$ & $15(10.9 \%)$ & $60(43.8 \%)$ & $234(39.0 \%)$ & $76(12.7 \%)$ & $62(10.3 \%)$ & $285(47.5 \%)$ \\
\hline no change & 99 (72.3 \%) & 118 (86.8 \%) & $122(89.1 \%)$ & 77 (56.2 \%) & $366(61.0 \%)$ & $522(87.3 \%)$ & 538 (89.7 \%) & $315(52.5 \%)$ \\
\hline
\end{tabular}

$\mathbf{N}$ - number of patients at each visit

${ }^{1}$ Change in insulin therapy at visit 1 due to initiation of lixisenatide therapy

${ }^{2}$ Occurrence of at least one change in insulin therapy between visit 1 and visit 3

${ }^{3}$ Change in OAD therapy at visit 1 due to initiation of lixisenatide therapy

${ }^{4}$ Occurrence of at least one change in OAD therapy between visit 1 and visit 3

\begin{tabular}{|c|c|c|c|c|c|}
\hline & $\mathbf{N}$ & baseline & after 6 months & difference & p value \\
\hline FPG (mmol/l) & 737 & $10.1( \pm 2.6)$ & $8.4( \pm 2.4)$ & $-1.8( \pm 2.8)$ & $p<0.001$ \\
\hline weight (kg) & 741 & $110.0( \pm 19.1)$ & $106.6( \pm 19.0)$ & $-3.5( \pm 5.4)$ & $p<0.001$ \\
\hline BMI $\left(\mathrm{kg} / \mathrm{m}^{2}\right)$ & 741 & $37.6( \pm 5.9)$ & $36.4( \pm 5.9)$ & $-1.2( \pm 1.8)$ & $p<0.001$ \\
\hline $\mathrm{SBP}(\mathrm{mm} \mathrm{Hg})$ & 741 & $138.7( \pm 13.2)$ & $136.2( \pm 12.6)$ & $-2.5( \pm 14.1)$ & $p<0.001$ \\
\hline $\mathrm{DBP}(\mathrm{mm} \mathrm{Hg})$ & 741 & $82.2( \pm 8.9)$ & $80.4( \pm 7.9)$ & $-1.71( \pm 9.7)$ & $p<0.001$ \\
\hline
\end{tabular}

BMI - body mass index DBP - diastolic blood pressure FPG - fasting plasma glucose SBP - systolic blood pressure 
culties, upper dyspeptic syndrome, epigastric cramps, belching, acute colitis, feeling of fullness in the stomach, dyspepsia, gastrointestinal intolerance and epigastric pain. No case of pancreatitis was reported. Regarding the SAEs a lower urinary tract infection was reported in one patient, moderately differentiated rectal adenocarcinoma in another patient, while in the third patient it was bariatric surgery - laparoscopic gastric banding. All SAEs were recovered at the end of the study.

Moreover, 5 additional AEs occurred in the non-eligible population; 1 of which was an SAE. Three of them were mild and 2 were moderate. All of them were gastrointestinal disorders and all were recovered at the end of the study.

No death was documented during the study.

\section{Physicians' satisfaction with treatment}

A total number of 149 physicians evaluated their satisfaction with the study treatment in 741 patients. The most of participating physicians were satisfied with the treatment as $37.9 \%$ of them described the treatment as very good and $29.6 \%$ as good. Less than $1 \%$ of the physicians described the treatment as very poor. The physicians selected their scores mainly based on the influence of the treatment on HbA1c levels and the body weight of the patients (Figure 4).

\section{Patients' perception of the treatment - Results of the TRIM-D questionnaire} To assess the impact of the treatment from patients' perspective the TRIM-D, itemized self-reporting questionnaire was employed in this study. Responses that were obtained from 652 patients at visit 1 and from 549 patients at visit 3 were subsequently evaluated. The patients' overall satisfaction with the ease and convenience of their medication improved between visit 1 and 3 ( 0.2 improvement in the mean; missing data for 103 patients). The biggest change, however, was in the patient's satisfaction with their medication's ability to manage their weight (0.6 improvement in the

\section{Table 5. Summary of adverse events}

\begin{tabular}{|l|c|}
\hline $\begin{array}{l}\text { adverse events } \\
\text { overall number of AEs }(\mathrm{n})\end{array}$ & $\begin{array}{c}\text { safety population } \\
(\mathrm{N}=772)\end{array}$ \\
$\begin{array}{l}\text { number }(\%) \text { of patients with at least one AE } \\
\mathrm{n}(\%)\end{array}$ & $23(3.0 \%)$ \\
\hline $\begin{array}{l}\text { number of patients with AE suspected to be } \\
\text { related to lixisenatide } \mathrm{n}(\%)\end{array}$ & $13(1.7 \%)$ \\
\hline $\begin{array}{l}\text { at least one AE suspected to be related to lixi- } \\
\text { senatide } \mathrm{n}(\%)\end{array}$ & $12(1.6 \%)$ \\
\hline $\begin{array}{l}\text { overall number of SAEs ( } \mathrm{n}) \\
\text { number (\%) of patients with at least one SAE } \\
\mathrm{n}(\%)\end{array}$ & $3(0.4 \%)$ \\
\hline $\begin{array}{l}\text { overall number of SAE suspected to be related } \\
\text { to lixisenatide } \mathrm{n}(\%)\end{array}$ & $0(0.0 \%)$ \\
\hline
\end{tabular}

AE - adverse events SAE - severe adverse events mean between visit 1 and visit 3). There was also a tangible improvement between visit 1 and 3 in indicators such as the patient's satisfaction with their medication's ability to control diabetes and prevent hypoglycemia and/or hyperglycemia ( 0.4 improvement in the mean), the medication's interference with the patients' meal planning and social activities $(0.2$ improvement in the mean), the medication's influence on the patients' daily activities and relationships with family and friends (0.2 improvement in the mean) and the negative feelings associated with diabetes medication ( 0.2 improvement in the mean). The overall compliance of the patients to their medication also improved between visit 1 and 3 (0.2 improvement in the average).

\section{Discussion}

Information on lixisenatide efficacy is mainly based on a series of placebo-controlled clinical trials (the GetGOAL Phase III Clinical Trial program) conducted over time periods ranging from 24 to 76 weeks. The trial program was comprehensive and included about 3000 patients who were inadequately controlled by $O A D$ and/ or basal insulin therapy. It thus investigated an efficacy and safety of lixisenatide in a wide range of therapeutic combinations in patients with different stages of T2DM. Results of meta-analysis of these trials demonstrated that lixisenatide achieved a durable improvement in glycemic control up to 76 weeks in patients who were inadequately controlled by OAD and/or basal insulin therapy. Importantly, its favorable efficacy outcome was reached alongside with a beneficial effect on body weight and a low risk of hypoglycemia or other side effects. Results also showed similar reduction in $\mathrm{HbA}_{1 \mathrm{c}}$ at 24 and 76 weeks when lixisenatide was administered as add-on therapy to OAD or basal insulin, with or without OAD and its good efficacy in decreasing both fasting and especially postprandial plasma glucose [18-20].

The present study was designed to comprehensively describe the use of lixisenatide in the management of T2DM in real-life conditions. The primary objective of the study was to evaluate the effectiveness and safety of lixisenatide over a 6 months' observational period in T2DM patients. This objective was assessed as the

\section{Figure 4. Physicians' satisfaction with treatment}

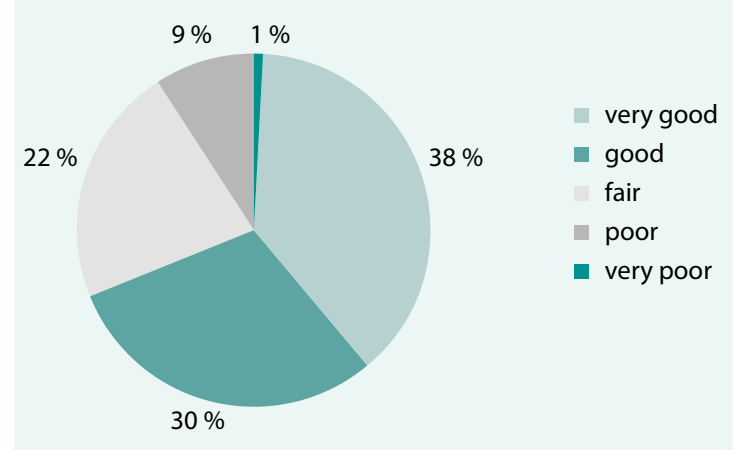


change in $\mathrm{HbA}_{1 c}$ levels as compared to baseline. Out of 826 patients included into the study, 737 were available for the primary analysis. Over the six-month follow-up period, a significant decrease $(\mathrm{p}<0.001)$ of $\mathrm{HbA}_{1 \mathrm{c}}$ was observed with the mean $\pm \mathrm{SD}$ change in $\mathrm{HbA}_{1 \mathrm{c}}$ levels of $-9.7 \pm 14.4 \mathrm{mmol} / \mathrm{mol}[-3 \pm 0.3 \% \mathrm{DCCT}]$. At the last follow-up visit, 137 patients (18.6\%) achieved a target $\mathrm{HbA}_{1 \mathrm{c}}<53 \mathrm{mmol} / \mathrm{mol}[<7 \%$ DCCT] and 564 patients (76.5\%) achieved a target decrease in $\mathrm{HbA}_{1 c}$ levels by at least $0.4 \%$. This improvement in glycemic control was accompanied by a parallel reduction in the mean FPG of $-1.7 \pm 2.8 \mathrm{mmol} / \mathrm{l}(\mathrm{p}<0.001)$. Changes in mean \pm SD body weight during the follow-up period were $-3.5 \pm$ $5.4 \mathrm{~kg}$ and this decrease was statistically significant $(p<0.001)$. The sustained effect of lixisenatide on efficacy parameters was demonstrated for majority of patients, except for those patients who did not have a decrease in $\mathrm{HbA}_{1 c}$ levels of greater than $0.4 \%$, as discussed below.

Although overall results of this study meet the expectations, with substantial changes in $\mathrm{HbA}_{1 \mathrm{c}}$ levels between the baseline and the last follow-up visit ( 6 months), only a subgroup of patients achieved satisfactory diabetes compensation, expressed as a proportion of patients who achieved $\mathrm{HbA}_{1 \mathrm{c}}<53 \mathrm{mmol} / \mathrm{mol}[<7 \%$ DCCT]. Even though the baseline $\mathrm{HbA}_{1 \mathrm{c}}$ values were lower within this subgroup (Fig. 2), these patients achieved the best outcome in terms of change in $\mathrm{HbA}_{1 c}$ values between the baseline and the last follow-up visit. Subgroup analysis showed that these patients were younger, with higher $\mathrm{BMI}$ and those with shorter history of diabetes and shorter duration of treatment with OADs and/or insulin. Not surprisingly, the patients who achieved the target $\mathrm{HbA}_{1 \mathrm{c}}<53 \mathrm{mmol} / \mathrm{mol}[<7 \% \mathrm{DCCT}]$ were also less likely to have microvascular complications (nephropathy, retinopathy and neuropathy) and had less concomitant diseases. Alongside with the above described characteristics patients achieving the target $\mathrm{HbA}_{1 \mathrm{c}}<53 \mathrm{mmol} / \mathrm{mol}$ $[<7 \% \mathrm{DCCT}]$ were less likely to need a change in insulin therapy and OAD treatment. Taken together, our data along with the results from randomized-controlled trials support the concept of an early initiation of GLP1 receptor agonist-based therapy as a very strong option to delay the progression of T2DM and its complications.

Another important observation in our study also is that in patients who did not achieve $\mathrm{HbA}_{1 c}$ decrease of more than $0.4 \%$ after three months of treatment initiation, there was a further decrease in $\mathrm{HbA}_{1 c}$ levels between the third and sixth month of treatment. This finding suggests that three months' period might be too short to fully assess the individual patient response to lixisenatide therapy and six months period appears to be more appropriate.

In our study, lixisenatide showed a predictable safety profile consistent with another GLP1 RAs. Overall 25 adverse events were reported in 23 patients (3.0 \% patients) and in 7 patients they led to discontinuation of the drug. The most frequent adverse events were gas- trointestinal disorders. Thirteen AEs were reported as related to the study drug. Only 3 severe adverse events were reported throughout the study in 3 patients and none of these events was in relation with the lixisenatide treatment. Most importantly a very low risk of risk of hypoglycemia was seen in the study, with 13 reported cases of symptomatic hypoglycemia and no case of severe hypoglycemia was reported.

The participating physicians expressed an overall satisfaction with the treatment, when $37.9 \%$ of them described the treatment as very good and $29.6 \%$ as good. Less than $1 \%$ of the physicians described the treatment as very poor.

Patient' satisfaction with anti-diabetic treatment, that was measured by using the TRIM-D questionnaire, increased between visit 1 and 3, with the biggest improvements reported in patient's satisfaction with their medication's ability to manage their weight ( 0.6 improvement in the mean between visit 1 and visit 3), and patient's satisfaction with their medication's ability to control diabetes and prevent hypoglycemia/hyperglycemia (0.4 improvement in the mean).

Overall these findings confirm the results of RCTs demonstrating the long-term effect (up to 76 weeks) of lixisenatide in the treatment of T2DM patients [20] and complement data on the its efficacy/safety profile gathered from RCTs, and further support positioning of lixisenatide within T2DM treatment options.

\section{Conclusion}

We conclude that this prospective observational study performed in everyday clinical practice in the Czech and the Slovak Republic demonstrated that the initiation of treatment with lixisenatide in patients with T2DM with inadequate glucose control on oral antidiabetic drugs with or without insulin resulted in a clinically relevant improvement of glucose control and body weight loss with a low incidence of symptomatic hypoglycemia and gastrointestinal side effects. Switching to lixisenatide may represent an effective and safe therapeutic option in patients with inadequate glycemic control, especially in those who are younger, have higher BMI and shorter diabetes duration.

\section{Limitations}

It is widely accepted that observational studies may play an important role in providing real-life outcomes, particularly in large cohorts with complex chronic diseases such as diabetes mellitus. Among the strength of the dataset the prospective collection of presented data on effectiveness and safety of lixisenatide there are some limitations to the current analysis deserving consideration: First, in single arm study design there is an inability to distinguish between the effect of the treatment, a placebo effect, and the effect of natural history. Furthermore, it is also difficult to interpret the response without a frame of reference for comparison. The representativeness for the subset of the Czech and 
the Slovak population with T2DM cannot be assessed. This is because we chose to recruit patients in specialized care but not the general population. This is unlikely to affect the overall conclusion.

Disclosures and acknowledgements

This study was sponsored by Sanofi Aventis, Czech Republic and Slovakia. The sponsor had no role in assigning treatments, dose decisions or patient identification during the study. The author had full access to all of the data in this study and takes complete responsibility for the integrity of the data and accuracy of the data analysis. The authors are grateful to all physicians and patients that participated in this study. During the peer review process, the manufacturer of insulin glargine $300 \mathrm{U} / \mathrm{mL}$ was also offered an opportunity to review this article. Changes resulting from comments received were made on the basis of scientific and editorial merit. Authors highly appreciate the biostatistical and editorial/writing support of Radka Štěpánová and Jaroslav Černý (APROVA s.r.o.)

Compliance with Ethics Guidelines. All procedures followed were in accordance with the ethical standards of the responsible committee on human experimentation (institutional and national) and with the Helsinki Declaration of 1964, as revised in 2013. Informed consent was obtained from all patients for being included in the study.

Data Availability. All data generated or analyzed during this study are included as a supplementary information file.

\section{References}

1. Hu FB. Globalization of diabetes: the role of diet, lifestyle, and genes. Diabetes Care 2011; 34(6): 1249-1257. Dostupné z DOI: <http:// dx.doi.org/10.2337/dc11-0442>.

2. [American Diabetes Association]. Classification and Diagnosis of diabetes. Diabetes Care 2017; 40(Suppl 1): S11-S24. Dostupné z DOI: $<$ http://dx.doi.org/10.2337/dc17-S005>.

3. Abdul-Ghani MA, Tripathy D, DeFronzo RA. Contributions of beta-cell dysfunction and insulin resistance to the pathogenesis of impaired glucose tolerance and impaired fasting glucose. Diabetes Care 2006; 29(5): 1130-1139. Dostupné z DOI: <http://dx.doi.org/10.2337/ diacare.2951130>.

4. Nathan DM, Genuth S, Lachin J et al. [Diabetes Control and Complications Trial Research Group]. The effect of intensive treatment of diabetes on the development and progression of long-term complications in insulin-dependent diabetes mellitus. N Engl J Med 1993; 329(14): 977-986. Dostupné z DOI: <http://dx.doi.org/10.1056/ NEJM199309303291401>.

5. Holman RR, Paul SK, Bethel MA et al. 10-year follow-up of intensive glucose control in type 2 diabetes. N Engl J Med 2008; 359(15): 15771589. Dostupné z DOI: <http://dx.doi.org/10.1056/NEJMoa0806470>.

6. Stratton IM, Adler Al, Neil HA et al. Association of glycaemia with macrovascular and microvascular complications of type 2 diabetes (UKPDS 35): prospective observational study. BMJ 2000; 321(7258): 405-412.

7. Inzucchi SE, Bergenstal RM, Buse JB et al. Management of hyperglycemia in type 2 diabetes, 2015: a patient-centered approach: update to a position statement of the American Diabetes Association and the European Association for the Study of Diabetes. Diabetes
Care 2015; 38(1): 140-149. Dostupné z DOI: <http://dx.doi.org/10.2337/ dc14-2441>.

8. [American Diabetes Association]. Standards of Medical Care in Diabetes - 2017. Introduction. Diabetes Care 2017; 40(Suppl 1): S1-S2. Dostupné z DOI: <http://dx.doi.org/10.2337/dc17-S001>.

9. Garber AJ, Abrahamson MJ, Barzilay JI et al. AACE comprehensive diabetes management algorithm 2013. Endocr Pract 2013; 19(2): 327-336.

10. Ahrén B. Insulin plus incretin: A glucose-lowering strategy for type 2-diabetes. World J Diabetes 2014; 5(1): 40-51. Dostupné z DOI: <http://dx.doi.org/10.4239/wjd.v5.i1.40>.

11. Nauck M. Incretin therapies: highlighting common features and differences in the modes of action of glucagon-like peptide-1 receptor agonists and dipeptidyl peptidase- 4 inhibitors. Diabetes Obes Metab 2016; 18(3): 203-216. Dostupné z DOI: <http://dx.doi.org/10.1111/ dom.12591>.

12. Uccellatore A, Genovese S, Dicembrini I et al. Comparison review of short-acting and long-acting glucagon-like peptide-1 receptor agonists. Diabetes Ther 2015; 6(3): 239-256. Dostupné z DOI: <http:// dx.doi.org/10.1007/s13300-015-0127-x>.

13. Prasad-Reddy L, Isaacs D. A clinical review of GLP-1 receptor agonists: efficacy and safety in diabetes and beyond. Drugs in Context 2015; 4: 212283. Dostupné z DOI: <http://dx.doi.org/10.7573/ dic.212283>.

14. Lyxumia Summary of product characteristics. Dostupné $z W W W$ : <http://www.ema.europa.eu/docs/en_GB/document_library/ EPAR_-_Product_Information/human/002445/WC500140401.pdf>. [Last updated April 03, 2017].

15. Bolli GB, Owens DR. Lixisenatide, a novel GLP-1 receptor agonist: efficacy, safety and clinical implications for type 2 diabetes mellitus). Diabetes Obes Metab 2014; 16(7): 588-601. Dostupné z DOI: <http:// dx.doi.org/10.1111/dom.12253>.

16. Shaefer CF Jr. Lixisenatide: A New Member of the Glucagon-Like Peptide 1 Receptor Agonist Class of Incretin Therapies. Clin Diabetes 2016; 34(2): 81-85. Dostupné z DOI: <http://dx.doi.org/10.2337/ diaclin.34.2.81>.

17. Raccah D, Gourdy $P$, Sagnard $L$ et al. Lixisenatide as add-on to oral anti-diabetic therapy: an effective treatment for glycaemic control with body weight benefits in type 2 diabetes. Diabetes Metab Res Rev 2014; 30(8): 742-748. Dostupné z DOI: <http://dx.doi.org/10.1002/ dmrr.2548>.

18. Ahrén B, Gautier JF, Berria R et al. Pronounced reduction of postprandial glucagon by lixisenatide: a meta-analysis of randomized clinical trials. Diabetes. Obes Metab 2014; 16(9): 861-868. Dostupné z DOI: $<$ http://dx.doi.org/10.1111/dom.12290>.

19. Charbonnel $B$, Bertolini $M$, Tinahones FJ et al. Lixisenatide plus basal insulin in patients with type 2 diabetes mellitus: a meta-analysis. J Diabetes Complications 2014; 28(6): 880-886. Dostupné z DOI: <http://dx.doi.org/10.1016/j.jdiacomp.2014.07.007>.

20. Broglio F, Mannucci $E$, Napoli $R$ et al. Beneficial effect of lixisenatide after 76 weeks of treatment in patients with type 2 diabetes mellitus: A meta-analysis from the GetGoal programme. Diabetes Obes Metab 2017; 19(2): 248-256. Dostupné z DOI: <http://dx.doi. org/10.1111/dom.12810>.

\section{Martin Haluzík, M.D., DSc., prof. \halm@ikem.cz}

Department of Diabetes, Institute for Clinical and Experimental Medicine (IKEM), Prague, Czech Republic www.ikem.cz

Doručeno do redakce 16. 1.2018

Prijato po recenzi 10. 3. 2018 